\title{
Marine Plastic Pollution in Asia: All Hands on Deck!
}

\author{
Beatriz GARCIA* \\ Lecturer, School of Law, Western Sydney University \\ B.Garcia@westernsydney.edu.au. \\ Mandy Meng FANG \\ Post-Doctoral Fellow, Asia Pacific Centre for Environmental Law, \\ National University of Singapore \\ lawfm@nus.edu.sg
}

\author{
Jolene LIN \\ Associate Professor, Faculty of Law, National University of Singapore; \\ Director, Asia Pacific Centre for Environmental Law \\ jolene.lin@nus.edu.sg
}

\begin{abstract}
Marine plastics pollution (MPP) is an alarming problem affecting many countries, particularly in the Asia-Pacific region, and generated mostly from land-based sources. Five Asian countries (i.e. China, Indonesia, the Philippines, Vietnam and Sri Lanka) have been identified as the largest sources of MPP globally. This article presents two cases studies focused on the two largest polluters: China and Indonesia. Both countries face similar challenges in dealing with plastic pollution. They have weak legal and institutional frameworks in place to deal with MPP. The two case studies also show that there have been more creative and effective measures taken at the domestic level by local governments and non-state actors, many of which involve partnerships among different stakeholders. This article argues that governance efforts to address MPP require an 'all hands-on deck' approach, involving multi-level and multi-actor strategies and targeted regulatory and non-regulatory measures. However, our findings also suggest that most efforts should be directed at the subnational level, from which the problem mainly originates. This article proposes a number of legal and policy
\end{abstract}

* We like to thank Fern Ling CHETTLE, Muhammad Nurshazny RAMLAN, Angela Mei FERGUSON, and Vanessa YUNG for their research assistance. 
recommendations, based on the lessons learned from the case studies, which can be instrumental in reducing the global MPP crisis.

\section{Keywords}

marine plastics - oceans - land-based pollution - sub-national governments - NG OS private sector - Asian region

\section{Introduction}

Over the past fifty years, plastic as a material has evolved remarkably, and its use has become ubiquitous in our modern-day societies. ${ }^{1}$ Innovation in the plastic industry has created low-cost, durable and versatile types of plastic; their end-use applications are countless. They range from medical and agricultural equipment to construction materials and food packaging. The production of plastic has outpaced that of almost every other material since the 1950s, which led to around 141 million tonnes of plastic waste, including from products and packaging in 2015 alone. 2 This high-usage level and poor 'end of life' management of plastic products has led to plastics becoming a major source of global marine pollution. Once plastic particles enter the marine environment, wind and ocean currents disperse them across the oceans. ${ }^{3}$ Marine plastics pollution (MPP) is an alarming problem because of its large scale, complexity, the increasing consumption of plastics both in developed and developing countries, and the pervasive adverse impacts on ecosystems and human health. ${ }^{4}$

In recent years, MPP has received increased attention. High-profile statements such as the $\mathrm{G}_{7}$ Leaders' statement in 2018 placed a spotlight on ocean plastics pollution, helping to push the issue up the international agenda. ${ }^{5}$

1 See Peter RYAN, 'A Brief History of Marine Litter Research' in Melanie Bergmann, Lars Gutow and Michael Klages (eds), Marine Anthropogenic Litter (Springer 2015).

2 UN Environment, Single-Use Plastics: A Roadmap for Sustainability (2018) United Nations Environment, Nairobi <https://wedocs.unep.org/bitstream/handle/20.500.11822/25496/single UsePlastic_sustainability.pdf $>$.

3 See, UN Environment (n 2 ) 2 and Andre ABREU and Maria Luiza PEDROTTI, 'Microplastics in the Oceans: The Solutions Lie on Land' (2019) 19 Journal of Field Actions, 62.

4 See section 2 below.

5 For the full version of the statement, see $\mathrm{G}_{7}$, 'Charlevoix Blueprint For Healthy Oceans, Seas and Resilient Coastal Communities' (2018) <https:/g7.gc.ca/wp-content/uploads/2018/o6/ HealthyOceansSeasResilientCoastalCommunities.pdf $>$. 
In November 2017, the Association of Southeast Asian Nations (ASEAN) Conference on Reducing Marine Debris in the ASEAN Region highlighted the urgent need for ASEAN countries to address this issue through regional cooperation to reduce plastics pollution at its originating sources (that is, to prevent land-based waste from entering the oceans in the first place). ${ }^{6}$ The United Nations Environment Assembly, as the governing body of UN Environment and the highest-level decision making body on environmental issues, has adopted a series of resolutions concerning marine plastic pollution and microplastics beginning with its first session (UNEA-1) in 2014. ${ }^{7}$ The primary aim is to establish a comprehensive and strong global governance structure. Although these resolutions and decisions are not legally binding on members nor clear in setting a specific roadmap, they play a significant role in guiding international policy-making and setting priorities concerning the marine plastic issue. ${ }^{8}$

According to research by German scientists, eight rivers in Asia are among the top ten sources of plastics pollution in the world's oceans. ${ }^{9}$ Another study found that four of Indonesia's rivers rank among the twenty most polluted in the world in terms of the metric tonnes of mismanaged plastic waste. ${ }^{10}$ Eighty three percent of the 4.4-12.7 million tonnes of land-based plastic waste that ends up in the ocean originates from just twenty countries. ${ }^{11}$ Amongst these countries, China, Indonesia, the Philippines, Vietnam and Sri Lanka are the top five most plastic-polluting states. The sources of marine litter are diverseranging from commercial and recreational ships and vessels to land-based

6 For a summary of the ASEAN Conference on Reducing Marine Debris in ASEAN Region (22-23 November 2017), see ASEAN Cooperation on Environment, 'Conference Summary' (2017) <http://environment.asean.org/wp-content/uploads/2017/12/Summary-of-ASEAN -Conference-on-Marine-Debris-26-Dec-2017.pdf>.

7 The United Nations Environment Assembly (UNEA) Resolutions include: UNEA-1 adopted on 27 June 2014; <UNEA-2, adopted on 23 May 2016; UNEA-3, adopted on 4 December 2017 and UNEA-4, adopted on 14 March 2019>.

8 Bharat H. DESAI, 'The Advent of the United Nations Environment Assembly' (2015) 19(2) ASIL Insights <https://www.asil.org/insights/volume/19/issue/2/advent-united-nations -environment-assembly>.

9 Christian SCHMIDT, Tobias KRAUTH and Stephan WAGNER, 'Export of Plastic Debris by Rivers into the Sea' (2017) 51(21) Environ. Sci. Technol. $12246<$ https://pubs.acs.org/ doi/10.1021/acs.est.7bo2368>.

10 Nature Communications, 'Table 1: Top 20 Polluting Rivers as Predicted by the Global River Plastic Inputs Model' Nature, 7 June 2017 <https://www.nature.com/articles/ ncomms15611/tables/1>.

11 Ansje LOHR, Heidi SAVELLI, Raoul BEUNEN, Marco KALZ, Ad RAGAS and Frank Van BELLEGHEM, 'Solutions for Global Marine Litter Pollution' (2017) 28 Current Opinion in Environmental Sustainability, 91. 
sources such as street litter and production waste. ${ }^{12}$ All this points to the salience of examining what needs to be done to tackle MPP in the Asian region.

Following a trend in international environmental law scholarship ${ }^{13}$ that seeks to go beyond state-centric approaches to global environmental issues, this article argues that sub-national (such as state/provincial) and local governments have core regulatory powers, particularly in waste management, that will prove critical to an effective response to MPP. In addition, companies play an important role in creating incentives to change consumer behaviour (that is, to use less plastics) and therefore nip the MPP issue in the bud. The findings from our research in this article on two case study jurisdictions-China and Indonesia-support these arguments. For example, we found that municipal authorities and private corporations were generally more proactive and creative in addressing MPP than the national governments and that multiple partnerships are being formed at the sub-national level. Nonetheless, we recognize the importance of national legal frameworks and the value of inter-state cooperation to set standards for environmental management. As such, we argue for effective engagement of local governments and corporations-alongside international organizations, national and sub-national governments and civil society - in a multi-level, multi-actor strategy to tackle MPP. ${ }^{14}$

Section 2 provides an overview of the sources of MPP and its adverse impacts on the environment. Section 3 presents China as the first case study. Section 4 presents the second case study of Indonesia. These countries were

12 Marcus HAWARD, 'Plastic Pollution of the World's Seas and Oceans as a Contemporary Challenge in Ocean Governance' (2018) 9(667) Nature <https://www.nature.com/articles/ s41467-018-03104-3.pdf>.

13 See, for example, Jolene LIN, 'The Emergence of Transnational Environmental Law in the Anthropocene' in Louis KOTZÉ (eds), Environmental Law and Governance for the Anthropocene (Hart, 2017); Gregory SHAFFER and Daniel BODANSKY, 'Transnationalism, Unilateralism and International Law' (2012) 1(1) Transnational Environmental law 31; Dan BODANSKY, 'Climate Change: Transnational Legal Order or Disorder?' in Terence C HALLIDAY and Gregory SHAFFER (eds), Transnational Legal Orders (Cambridge University Press, 2015) 287; Jolene LIN and Joanne SCOTT, 'Looking Beyond the International: Key Themes and Approaches of Transnational Environmental Law' 1(1) Transnational Environmental Law (2012) 23-29; Veerle HEYVAERT, Transnational Environmental Regulation and Governance (Cambridge University Press, 2018); Hari M. OSOFSKY, 'Climate Change and Crises of International Law: Possibilities for Geographic Re-envisioning' (2001) Case Western Reserve Journal of International Law 423.

14 See Elizabeth A. KIRK and Naporn POPATTANACHAI, 'Marine Plastics: Fragmentation, Effectiveness and Legitimacy in International Lawmaking' (2018) 27(3) Review of European, Comparative and International Environmental Law (RECIEL) 222. This RECIEL Special Issue on 'Plastics Regulation' (2018) 27(3) also contains other relevant articles and information. 
selected as they are the two top marine plastic polluters globally. In Section 5, we argue for the adoption of an 'all hands on deck' approach and, drawing from the findings in sections 3 and 4, make a number of key policy recommendations. They include strengthening local waste management and recycling laws, public awareness campaigns to educate citizens about the impact of plastic consumption habits, and engaging corporations to include the reduction of plastics use in their corporate social responsibility (CSR) policies and building multi-stakeholder and cross-border partnerships. Section 6 draws some conclusions.

\section{Sources of Plastic Waste and the Impacts of Plastics Pollution}

In the past few decades, the pervasiveness of MPP as a severe threat to the environment has become an increasingly significant concern for governments, scientists, non-governmental organizations, and citizens worldwide. ${ }^{15}$ More than 8 million tonnes of plastic leak into the oceans every year, of which more than $80 \%$ of marine plastic waste comes from land-based sources as discarded plastic that has been improperly managed leaks into the oceans. ${ }^{16}$ Two thirds of land-based plastic waste that ends up in the oceans originates from waste that has been left uncollected (that is, disposed of into the environment), while the remaining one third constitutes leakage from improper waste management systems. ${ }^{17}$ According to JAMBECK et al, the top five marine plastic polluter countries (China, Indonesia, Philippines, Vietnam and Sri Lanka) have contributed to more than half of global marine plastic pollution. ${ }^{18}$ Eight out of the

15 See UNEP, Frontiers 2017 Emerging Issues of Environmental Concern (2017) United Nations Environment Programme, Nairobi <https://www.unenvironment.org/resources/ frontiers-2017-emerging-issues-environmental-concern >; Kara Lavender LAW, 'Plastics in the Marine Environment' (2017) 9 Annual Review of Marine Science 205; UnEP, Marine Plastic Debris and Microplastics - Global Lessons and Research to Inspire Action and Guide Policy Change (2016) United Nations Environment Programme, Nairobi.

16 See Ocean Conservancy and McKinsey Center for Business and Environment, 'Stemming the Tide: Land-Based Strategies for A Plastic-Free Ocean' (2015) Ocean Conservancy https://oceanconservancy.org/wp-content/uploads/2017/04/full-report -stemming-the.pdf, 7; Laura PARKER, 'We Made Plastic. We Depend on It. Now We're Drowning In It' (June 2018) National Geographic <https://www.nationalgeographic.com/ magazine/2018/06/plastic-planet-waste-pollution-trash-crisis/>.

17 Ibid.

18 Jenna R JAMBECK et al, 'Plastic Waste Inputs from Land to the Ocean' (2015) 347(6223) Science 768,769 . 
ten heaviest polluters are countries in Asia, ${ }^{19}$ which highlights the importance of tackling MPP in this region.

Plastic waste that enters the oceans have a multitude of cumulative and long-lasting impacts on human health and marine life, and also affect certain economic sectors and navigation. The dangers posed by plastic waste to marine life, in particular, are severe in a variety of ways. Marine animals can unwittingly ingest plastics, which creates life-threatening problems such as blockage of their digestive systems. ${ }^{20}$ In addition, animals may become tangled in plastic waste, which can be fatal or cause a range of life-threatening consequences, such as long-term movement restriction. ${ }^{21}$ Plastic waste can also pose 'uncertain physiological and toxicological risks' in marine habitats, for instance coral reefs. ${ }^{22}$ It is estimated that 11.1 billion plastic items have been entangled in the corals, and this is projected to increase by $40 \%$ by $2025 .{ }^{23}$ The degradation of marine habitats can ultimately lead to extinction of particular marine species.

There is emerging evidence that plastic waste and micro-plastics, ${ }^{24}$ when ingested by fish or other marine life, can inadvertently enter the human food

19 Ibid. These countries are: China, Indonesia, Philippines, Vietnam, Sri Lanka, Thailand, Malaysia and Bangladesh.

20 Laura PARKER, 'Animals Eat Ocean Plastic Because It Smells Like Food' (National Geography, 9 November 2016)<https://news.nationalgeographic.com/2016/11/animals-eat -ocean-plastic-because-of-smell-dms-algae-seabirds-fish/>.

21 Richard THOMPSON, 'Plastic Entanglements Increase 40\% For Marine Animals' (Ocean Health Index, 22 August 2013) <http://www.oceanhealthindex.org/news/Death _By_Plastic $>$.

22 NOAA, '2016 NOAA Marine Debris Program Report on Marine Debris Impacts on Coastal and Benthic Habitats' (2016) National Oceanic and Atmospheric Administration <https:// marinedebris.noaa.gov/sites/default/files/publications-files/Marine_Debris_Impacts_ on_Coastal_\%26_Benthic_Habitats.pdf>.

23 Joleah LAMB and others, 'Plastic Waste Associated with Disease on Coral Reefs' (2018) 359 (6374) Science 460.

24 Microplastics are usually defined as plastic items, which measure less than $5 \mathrm{~mm}$ in their longest dimension. Plastics that reach the ocean will gradually break down into eversmaller pieces due to sunlight exposure, oxidation, and the physical action of waves, currents, and grazing by fish and birds. See, Fiona HARVEY and Jonathan WATTS, 'Microplastics Found in Human Stools for the First Time' (22 October 2018) The Guardian $<$ https://www.theguardian.com/environment/2018/oct/22/microplastics-found-in -human-stools-for-the-first-time>. That study, entitled 'Assessment of Microplastic Concentrations in Human Stool—Preliminary Results of a Prospective Study', by Philipp SCHWABL et al was presented at the 26th United European Gastroenterology (UEG) Week in Vienna on 23 October 2018, <https://www.ueg.eu/education/document/ assessment-of-microplastic-concentrations-in-human-stool-preliminary-results-of-a -prospective-study/18036o/>. 
chain. ${ }^{25}$ Although knowledge and research about this health hazard is still underdeveloped, ${ }^{26}$ it is understood that MPP can potentially compromise food security, food safety and human health. Also, plastics in the oceans can travel large distances and become a transport medium for various chemical contaminants. $^{27}$

MPP can also have adverse impacts on the economy, such as the fishing, navigation and tourism sectors. ${ }^{28}$ The overall financial damage of plastics that enter the marine environment is estimated to reach around US\$13 billion each year, according to the UN Environment Assembly report. ${ }^{29}$ The greater the dependence of countries and local areas on coastal tourism or the fishing industry, the more vulnerable they are. The economic costs of beach clean-ups and actions to remove plastics are also high, and of variable effectiveness. ${ }^{30}$

A less noticeable impact of MPP is on navigation. Some marine plastics waste, such as abandoned fishing gear, can entangle anchors and foul the propellers of vessels, which may lead to vessel breakdowns and human casualties

25 See, UN Environment (n 2) 14; Frederic GALLO et al, 'Marine Litter Plastics and Microplastics and their Toxic Chemicals Components: The Need for Urgent Preventive Measures' (2018) 30(1) Environmental Science Europe; UNE P Frontiers 2017 (n 15) 13-16.

26 Kara Lavender LAW and Richard THOMPSON, 'Microplastics in the Seas' (2014) $345(6193)$ Science 144.

27 Emma TUETEN and others, "Transport and Release of Chemicals from Plastics to the Environment and to Wildlife' (2009) 364 (1526) Philosophical Transactions of the Royal Society B: Biological Sciences 2027, 2030.

28 Alistair MCILGORM, Harry CAMPBELL and Michael RULE, 'The Economic Cost and Control of Marine Debris Damage in the Asia-Pacific Region' (2011) 54 Ocean \& Coastal Management 643 .

29 For the full version of report, see UNEP, UNEP Year Book 2014: Emerging Issues in Our Global Environment (2014) United Nations Environment Programme, Nairobi http:// wedocs.unep.org/handle/20.500.11822/9240; see also Elizabeth MATSANGON, 'Counting the Cost of Plastic Pollution' (2 July 2018) World Finance <https://www.worldfinance .com/markets/counting-the-cost-of-plastic-pollution $>$. The economic cost of selected litter-reducing and plastic waste management strategies is discussed in the report by Olha KRUSHELNYTSKA 'Solving Marine Pollution: Successful Models to Reduce Wastewater, Agricultural Runoff, and Marine Litter, World Bank Group, Pollution Management \& Environmental Health and Global Partnership for Oceans (2018) 24.

30 See for example, Laura PARKER et al, 'Significant plastic accumulation on the Cocos (Keeling) Islands, Australia,' (2019) 9 Scientific Reports 6. According to this study, 'with an estimated 2,000 oceanic islands worldwide, and thousands of new plastic items washing up on remote beaches every day, clean-ups cannot keep pace.' Research produced by Columbia Marine Debris Research Team shows that for New York City, the annual cost for beach and waterway clean-up has reached \$271 million. See, 'Quantifying the Financial Costs to Communities of Managing Trash in the Hudson-Raritan Estuary' (May 2015) <http://mpaenvironment.ei.columbia.edu/files/2015/o6/Quantifying-the-Costs -of-Managing-Marine-Debris_FINAL.pdf 10>. 
in extreme cases. ${ }^{31}$ It poses concerns to the safety of navigation, and also involves expenses related to the repair and replacement of equipment.

\section{$3 \quad$ Marine Plastic Pollution in China}

This section examines the underlying causes of MPP in China and the measures that have been taken to address the problem. Part of the analysis undertaken here includes an assessment of whether, and to what extent, Chinese laws, policies and actions taken at the national and sub-national levels have been effective in tackling plastic pollution.

\subsection{Plastic Pollution in China}

China has a long coastline, from the Bohai Sea, the Yellow Sea, the East China Sea to the South China Sea. According to recent research, China is the world's largest source of MPP. ${ }^{32}$ Nearly $30 \%$ of global plastic waste comes from China. ${ }^{33}$ In terms of per capita pollution, China ranks lower than the US, but it is far above other countries in Asia, such as Indonesia and the Philippines. ${ }^{34}$ That the lion's share of global MPP originates from China indicates that the country generates a very substantial amount of plastic waste.

There are four main reasons why China generates such high volumes of MPP. First, China's coastal population density is the highest globally, with major coastal cities such as Hong Kong, Shanghai, Guangzhou and Tianjin. ${ }^{35}$ The coastal areas are responsible for the discharge of approximately 1.3 million to 3.5 million metric tonnes of plastics into the oceans each year. ${ }^{36}$ This finding accords with the theory of JAMBECK et al that a nation's population density

31 NOAA, 'Marine Debris Impacts' U.S. National Oceanic and Atmospheric Administration Marine Debris Program, 26 December $2018<$ https://marinedebris.noaa.gov/discover -issue/impacts $>$.

$32 \quad$ JAMBECK et al (n 18), 769.

33 Ibid

34 Hannah RITCHIE and Max ROSER, 'Plastic Pollution' OurWorldInData.org, September $2018<$ https://ourworldindata.org/plastic-pollution>.

35 Gwynn GUILFORD, 'China is Responsible for A Quarter of the Plastic Clogging Our Oceans' Quartz, 13 February 2015 <https:/qz.com/342922/china-is-responsible-for-a -quarter-of-the-plastic-clogging-our-oceans/>; Ernest KAO, 'More than 17 Million Pieces of Plastic Waste Flushed into Sea via Hong Kong's Shing Mun River Each Year' (18 October 2018) <https://www.scmp.com/news/hong-kong/health-environment/article/ 2169129/more-17-million-pieces-plastic-waste-flushed-sea >.

36 JAMBECK et al (n 18$)$. 
within $5^{\circ}$ kilometres of the coast is the primary determinant of the scale of its land-based marine pollution. ${ }^{37}$

Secondly, the consumption of plastics in China has been increasing rapidly in line with its rapid economic growth since the 1980 os. $^{38}$ For example, Chinese consumers purchase around a quarter of the world's plastic bottles. ${ }^{39}$ The overconsumption of plastics amongst the Chinese has worsened due to the increasing popularity of online shopping, with associated plastic packaging, and the booming food takeaway business in recent years. ${ }^{40}$

Thirdly, until recently, China was the world's largest importer of plastic waste, some of which has been smuggled into the country due to the profitability of this business. ${ }^{41}$ In 2016, China imported 7.3 million tonnes of plastic waste from developed countries including the UK, the US and Japan. ${ }^{42}$ It has been estimated that nearly half of the planet's plastic waste (e.g. single-use bottles, food wrappers, plastic bags, etc.) has been sent to China in the past two decades. ${ }^{43}$ Once plastic waste is imported into China, the waste could be recycled and converted into other plastic goods, but less valuable plastic waste is usually discarded without proper management, which might end up in China's waterways and oceans. ${ }^{44}$ Against this background, the Chinese central

37 Ibid.

38 China's GDP had grown from US $\$ 1.211$ trillion in 2000 to US $\$ 12.238$ trillion in 2017. For the statistics of China's GDP growth, see World Bank Open Data, 'China' <https://data.world bank.org/country/china>.

39 China Development Brief, ' $1 / 4$ of Global Plastic Bottles Have Been Purchased by China: the Urgent Need to Tackle Plastic Wastes' China Development Brief, 29 June $2017<$ http:// www.chinadevelopmentbrief.org.cn/news-19702.html>.

40 See Guanghan SONG et al, 'Packaging Waste from Food Delivery in China's Mega Cities' (2018) 130 Resources, Conservation \& Recycling 226; Huabo DUAN and others, 'Post-consumer Packaging Waste from Express Delivery in China' (2019) 144 Resources, Conservation \& Recycling 137; 'China's Food-delivery Business is Booming. So is Waste' The Economist, 19 October 2017 <https://www.economist.com/china/2017/10/19/chinas -food-delivery-business-is-booming-so-is-waste>; 'Delivery Companies to the Fore in Fight against Plastic Waste' China Daily, 23 February $2018<$ http://www.chinadaily.com .cn/a/201802/23/WS5a8f55doa3106e7dcc13d7a4.html>.

41 LiJING, 'China Produces About A Third of Plastic Waste Polluting the World's Oceans, Says Report' (South China Morning Post, 13 February 2015 <http://www.scmp.com/article/1711744/ china-produces-about-third-plastic-waste-polluting-worlds-oceans-says-report> .

42 Sandra LAVILLE, 'Chinese Ban on Plastic Waste Imports Could See UK Pollution Rise' The Guardian, 7 December 2017 <https://www.theguardian.com/environment/2017/dec/ 07/chinese-ban-on-plastic-waste-imports-could-see-uk-pollution-rise>.

43 Ibid.

44 Alexander H. TULLO, 'Fighting Ocean Plastics at the Source' (2018) 96(16) Chemical \& Engineering News <https://cen.acs.org/materials/polymers/Fighting-ocean-plastics -source/96/i16>; Leslie HOOK and John REED, 'Why the World's Recycling System 
government has imposed an import waste ban, ${ }^{45}$ which was adopted in 2018 and has led to a drastic drop of China's plastic imports of $99 \%{ }^{46}$ The ban will improve the domestic environment and recycling of domestic waste. According to the newly formed Ministry of Ecology and Environment, the import waste ban represents 'a symbolic measure for the creation of an ecological civilization in China: ${ }^{47}$ From a global perspective, China's waste ban is bound to have far-reaching implications and force other countries to significantly alter their waste management policies instead of relying on China as an export market. ${ }^{48}$ Although some developed countries, such as those in the European Union and the United States, have voiced their concerns and disagreement with China's move ${ }^{49}$ it is time for them to invest in efficient and sustainable management of waste.

Finally, the plastic waste-recycling sector in China has largely been informal, fragmented and under-invested, resulting in significant inefficiencies. ${ }^{50}$ In general, poor recycling practices are a persistent problem in all of China's large-sized cities. There are usually only informal recycling networks consisting of small and medium-sized factories that operate obsolete equipment and technology, which are grossly inadequate for tackling China's ever-growing amounts of waste. ${ }^{51}$

However, some actions taken in China to address MPP have the potential to substantially reduce MPP globally and could be replicated in other Asian

Stopped Working' Financial Times, 25 October $2018<$ https://www.ft.com/content /36oe2524-d71a-11e8-a854-33d6f82e62f8>.

45 The initial import ban outlawed 24 types of recyclables and solid waste from entering the country. It also toughened the standards on impurities levels in imported waste materials, making them almost impossible to comply with. The ban was widened in 2019 to cover 32 types of scrap for recycling and reuse, including post-consumer plastics.

46 Cheryl KATZ, 'Piling Up: How China's Ban on Importing Waste Has Stalled Global Recycling' Yale Environment 360, 7 March 2019 <https://e36o.yale.edu/features/piling -up-how-chinas-ban-on-importing-waste-has-stalled-global-recycling>.

47 'The Minutes of Ministry of Ecology and Environment's Press Conference on March 2019' (29 March 2019) <http://www.mee.gov.cn/xxgk2018/xxgk/xxgk15/201903/t20190329_697819 .html>.

48 For discussions on transnational environmental law, please see Jolene Lin (n 13); Gregory SHAFFER and Daniel BODANSKY (n 13); Jolene LIN and Joanne SCOTT (n 13); Veerle HEYVAERT (n 13); Hari M Osofsky, (n 13).

49 Yen Nee LEE, "The World is Scrambling Now that China is Refusing to be a Trash Dumping Ground' 16 April 2018, CNBC <https://www.cnbc.com/2018/04/16/climate-change-china -bans-import-of-foreign-waste-to-stop-pollution.html>.

5o Pieter VAN BEUKERING and others, 'Trends and Issues in Plastics Cycle in China with Special Emphasis on Trade and Recycling' (1997) CREED Working Paper Series No. 16, 3 <http://www.prem-online.org/archive/17/doc/creed16e.pdf >.

Ibid 10. 
jurisdictions that have high rates of plastic pollution. The following sections look at how China's central government, provincial and local governments, and non-state actors have sought to reduce MPP.

\subsection{National Legal and Institutional Frameworks}

China does not have a national law that specifically addresses the issue of MPP. However, references to MPP can be found in some national laws and administrative regulations ${ }^{52}$ on marine environmental protection, waste dumping control and plastic products regulations.

The Marine Environmental Protection Law contains China's basic legal framework on marine environmental protection. ${ }^{53}$ Under this law, China's State Council, the highest executive authority, may issue rules and regulations that deal with marine pollution. The central government has issued regulations concerning, for example, the Control Over Dumping Wastes into the Sea Waters, ${ }^{54}$ and the Prevention and Control of Land-based Pollutants from Polluting Seas. ${ }^{55}$ Entities and individuals that violate the laws and regulations

52 According to China's Law on Legislation, enacted in 2000, law is made by the National People's Congress (NPC) and its Standing Committee. Administrative regulations are made by the State Council, and must be promulgated by an Order of the State Council. The ministries and commissions under the State Council, along with other agencies with administrative functions directly under the State Council can issue departmental rules. The provincial people's congresses and their standing committees make local regulations.

53 The Marine Environmental Protection Law was adopted on August 23, 1982 and revised on December 25, 1999 by the Standing Committee of the National People's Congress. Although it does not specifically deal with marine plastic pollution, the new Marine Environmental Protection Law stipulates: 'land-based pollution treatment will be an essential part of marine environment protection,' full text available (in Chinese) at <http://www.npc.gov.cn/wxzl/gongbao/2000-12/17/content_5004762.htm>. See also Keyuan ZOU, 'People's Republic of China: Curbing Marine Environment Degradation, China's New Legislation' (2001) 16 International Journal of Marine and Coastal Law 347; Mitchell SILK, China's Marine Environmental Protection Law: The Dragon Creeping in Murky Waters (Occasional Papers/Reprints Series in Contemporary Asian Studies, 1985); Nengye LIU, 'Water and Oceans Law' in QIN Tianbao (ed), Research Handbook on Chinese Environmental Law (Elgar, 2015), 81-90.

54 The PRC State Council issued China's Regulations on the Control Over Dumping Wastes into the Sea Waters on 6 March 1985. The full text is available at <http://english.mee.gov .cn/Resources/laws/regulations/Marine_Environment/200710/t20071022_111652.shtml>.

55 The PrC State Council issued China's Regulations on the Prevention and Control of Land-based Pollutants from Polluting Season 22 June 1990. The full text is available at <http://english.mee.gov.cn/Resources/laws/regulations/Marine_Environment/200710/ t20071022_111647.shtml>. 
face various forms of punishment such as, administrative warnings, fines, or criminal responsibility. ${ }^{56}$

The institutional framework regarding marine environmental protection in China is complex, as it involves several agencies with ill-defined roles and responsibilities. There are various ministries (e.g. Ministries of Ecology and Environment, ${ }^{57}$ Industry, Agriculture, Housing, among others) that can make decisions regarding MPP. ${ }^{58}$ None of them, however, has an explicit legal or political mandate to regulate MPP. This results in poor coordination amongst the relevant institutions and under-regulation due to the ambiguous allocation of regulatory power and responsibilities. Nevertheless, the creation of the Ministry of Ecology and Environment in 2018 has the potential to address the fragmentation of environmental protection responsibilities and to unify enforcement responsibilities. ${ }^{59}$

The State Council has issued various administrative decrees, which complement national environmental laws and regulations. An early highprofile move made by the State Council, in 2008, was the passage of a nationwide limit on retailers distributing free plastic bags as well as production, sale, and use of ultra-thin plastic bags. ${ }^{60} \mathrm{~A}$ broader-ranging reform plan approved in 2017 proposed to cut down millions of tonnes of plastic imported from foreign countries. ${ }^{61}$ The State Council also issued the Interim Regulation on Express

$56 \quad$ Ibid art 34 .

57 The Ministry of Ecology and Environment superseded the Ministry of Environmental Protection in 2018. It is a department of the State Council of the People's Republic of China; see WANG Jinpeng 'Reform of China's Environmental Governance: The Creation of a Ministry of Ecology and Environment', Chinese Journal of Environmental Law 2 (2018) 112-117.

58 Juying WANG and Linzhen LIN, 'Global Ocean Governance in Addressing Plastic and Micro-plastic Pollution' (2018) 26(4) Pacific Journal 79, 87.

59 WANG (n 57) 114.

6o PrC State Council, 'Notice of the General Office of the State Council on Restricting the Production, Sale and Use of Plastic Shopping Bags', PRC State Council Website, 8 January 2008 <http://www.gov.cn/zwgk/2008-01/08/content_852879.htm>. The notice issued by the State Council constitutes administrative regulation and is inferior to law in terms of legal effect. This renders the enforcement of this notice problematic. See also Jennifer CLAPP and Linda SWANSTON, 'Doing Away with Plastic Shopping Bags: International Patterns of Norm Emergence and Policy Implementation' (2009) 18(3) Environmental Politics 315, 321.

61 PRC State Council, 'Notice of the General Office of the State Council on Issuing the Implementation Plan for Prohibiting the Entry of Foreign Garbage and Advancing the Reform of the Solid Waste Import Administration System' (PRC State Council Website, 18 July 2017) http://www.gov.cn/zhengce/content/2017-07/27/content_5213738.htm. 
Delivery in 2018, ${ }^{62}$ which encourages the use of recyclable and degradable packaging materials. At supermarkets and shopping malls, customers must pay a fee of around 0.3 Rм (\$0.04) for plastic bags, which is arguably a profitable business for supermarkets and malls. ${ }^{63}$ Unfortunately many retailers, such as small shops and individual vendors, are still using thin plastic bags and thus violating the limit without any punishment, due to lack of monitoring and enforcement from the authorities. ${ }^{64}$ The extent to which the ban, which has a limited scope, has fundamentally changed consumers' shopping habits and promoted the expansion of environmentally friendly alternatives to plastic bags is therefore open to question.

National tax laws can also play a role in reducing plastic production by manufacturers. In China, the 2018 Environmental Protection Tax Law targets public institutions and private companies (individuals and households are excluded). ${ }^{65}$ These entities pay taxes for example if their activities result in noise, air and water pollutants and solid waste. ${ }^{66}$ The Chinese Central Government defines upper limits of the tax rates and allows local governments to determine sub-national tax rates. ${ }^{67}$

Laws and guidelines adopted in China on product standards can also help reduce plastic use. For example, China's General Administration of Quality Supervision, Inspection and Quarantine, a ministerial-level department under the State Council, has elaborated two product standards for manufacturers: the 2013 Product Standard on Plastics, particularly polystyrene compounds, ${ }^{68}$ and the 2014 Product Standard on Paper and Plastics, including laminated

$62 \quad$ PRC State Council Decree 697, 'The Interim Regulation on Express Delivery'. PRC State Council Website, 2 March 2018 <http://www.gov.cn/zhengce/content/2018-03/27/content_ $5277801 . h t m>$.

63 Yingchao LI, 'The Difficulty of Implementing Plastics Ban and the Loopholes Retailers Can Enjoy: Primary Reason is Low Level of Support from Consumers' (People.cn, 22 February 2016) <http://env.people.com.cn/n1/2016/0222/c1010-28138042.html>.

64 According to the investigation of China Zero Waste Alliance; see Mandy ZUO, 'Lawsuit Turns Up the Heat on China's Food Delivery Market Over of Waste'. South China Morning Post, 17 September 2017 <https://www.scmp.com/news/china/society/article/211145o/ lawsuit-turns-heat-chinas-food-delivery-market-over-tide-waste>.

65 Article 2 of the 2018 Environmental Protection Tax Law (China), passed by the National People's Congress of on 25 December 2016. The full text is available at <http://www.npc .gov.cn/npc/xinwen/2016-12/25/content_2004993.htm>.

66 Article 9.

67 Article 6.

68 China's General Administration of Quality Supervision, Inspection and Quarantine issued guidance on the standard of recycled polystyrene compound on 6 September 2013, which took effect on 31 January 2014, full text available at $<\mathrm{http} / /$ csres.com/detail/234898 .html>. 
films and pouches for food packaging. ${ }^{69}$ These standards, however, are not legally binding.

It can be argued that the Chinese central government has focused on tackling air and water pollution and devoted limited attention and capacity to addressing MPP. ${ }^{70}$ Marine environment protection, and plastics pollution, do not appear to be a top priority in China's environmental policy agenda. ${ }^{71}$ In any case, even if national laws on MPP are adopted, their implementation and enforcement may prove difficult, as observed with other environmental laws in China. ${ }^{72}$

\subsection{Sub-national Framework in China}

Contrary to the situation at the national level, there have been significant efforts taken at the sub-national level to address plastics pollution, which are driven by local governments and non-state actors, including NGOs and corporations. As discussed below, these efforts represent more creative and dynamic responses to MPP than those taken at the national level.

\subsubsection{Local Governments}

Governments in coastal provinces and cities have generally taken more responsibility in tackling MPP than those in inland cities due to their proximity to the ocean. The rapid economic development of China's coastal areas also means that there is more funding and capacity for local governments in these

69 China's General Administration of Quality Supervision, Inspection and Quarantine issued guidance on the Standard of Paper and Plastics on laminated films and pouches for food packaging on 8 July 2014, which took effect on 1 March 2015, full text is available at $<$ http://csres.com/detail/244441.html $>$.

70 For example, the Chinese Government announced as a priority, in its 12th Five Year Plan, the fight against air, water and soil pollution. The 13th Five-Year Plan on Ecological and Environmental Protection only makes brief mention to plastic pollution. Full text is available at <http://www.gov.cn/xinwen/2016-12/05/content_5143613 .htm\#1>. See also LIU Qin, 'China Promises Restrictions on Plastic Waste' China Dialogue, 21 February 2018 <https://www.chinadialogue.net/article/show/single/en/10412 -China-promises-restrictions-on-plastic-waste >.

71 Sulan CHEN and Juha UITTO, 'Governing Marine and Coastal Environment in China: Building Local Government Capacity Through International Cooperation' (2003) 6 China Environmental Series 67, 71.

72 See XU Guangdong and Michael FAURE, 'Explaining the Failure of Environmental Law in China' (2016) 29(2) Columbia Journal of Asian Law 1; MA Yun, 'Vertical Environmental Management: A Panacea to the Environmental Enforcement Gap in China?' Chinese Journal of Environmental Law 1 (2017) 37-68; Richard ZHANG Qing and Benoit MAYER, 'Public Interest Environmental Litigation in China' Chinese Journal of Environmental Law 1 (2017) 202-228. 
localities. Some local governments have adopted binding laws and regulations, while others use mostly soft-law (non-binding) instruments.

The governments of Qinghuangdao (Hebei Province), Tianjin, Rizhao (Shandong Province), Lianyungang (Jiangsu Province), Shanghai, Xiamen (Fujian Province) and Shenzhen (Guangdong Province) have made organized and systematic efforts to remove plastic waste from rivers. ${ }^{73}$ They have established waste monitoring systems, professional clean-up teams, and built waste collection facilities to prevent waste dumping into rivers, harbours and oceans. ${ }^{74}$

In 2013 the Standing Committee of the Shanghai People's Congress adopted the Regulation on Reducing Packages in Shanghai that imposes significant fines on the selling of excessively-packaged commodities. ${ }^{75}$ This is the firstever regulation issued by a local government in China that deals with excessive packaging. The government has also encouraged the public to use hotlines, emails, and online messaging systems to report retailers in Shanghai that sell excessively packaged commodities. ${ }^{76}$

The Jilin provincial government passed the Regulation Prohibiting the Producing, Selling and Providing One-time Non-Degradable Plastic Bags and Tableware in $2015 .{ }^{77}$ The Jilin government assigned a team of officials to supervise the enforcement of the plastics ban, and also actively promote awareness campaigns in shopping malls, supermarkets and small markets. ${ }^{78}$ An increasing number of companies based in Jilin biological innovation industry area (e.g. Shengda Biological and Zhengjiang Haizheng) have started to invest more

73 Rendu Ocean, 'Research Report on Monitoring Several Chinese Beach Waste 2016' Rendu, June $2017<$ http://www.renduocean.org/\%E7\%Ao\%94\%E7\%A9\%B6\%E6\%88\%9o\%E6 $\% 9 \mathrm{E} \% 9 \mathrm{C} /$ ccmc_report_2016.pdf 21>.

74 Ibid.

75 See, Shanghai Municipal People's Congress, 'Rules on Reducing Commodities Packaging' Shanghai Municipal People's Congress Website, 27 August 2013 <http://www.spcsc.sh.cn/ n1939/n2440/n2464/u1ai11037.html, adopted in November 21, 2012>.

$7^{6}$ See, Shanghai Government website specifies the details in how to report on excessive packaging Shanghai Government, 'Deputy Chief of the City Quality and Technology Supervision Bureau Yang Jiangbo Answering the Questions' Shanghai Government Website, 16 September 2013 <http://chat.sh.gov.cn/Chatting/template/sh_red/wtjd.aspx? ChatId $=224>$.

77 The regulation was passed by the Jilin Government as Governmental Decree 244, see, Jilin Government, 'The Notice on the Provincial People's Government of Jilin Forwarding Provincial National Development and Reform Committee and other Departments' Opinions on Implementing the Prohibition of Producing, Selling and Providing Disposable and Non-Degradable Plastic Bags and Cutlery', (Jilin Government Website, 7 January 2015 <http://zb.jl.gov.cn/test2014zb_3929o/201422/201422JZBF/201501/t20150107_1889206.html>. Ibid. 
in the production of degradable plastic products, the potential of which is bound to grow due to the incentive policy. The cooperation between the Jilin government, civil society and private companies has had a positive impact in reducing plastics consumption and in raising awareness among consumers.

\subsubsection{Non-state Actors}

NGOs in China have been very active in investigating plastic pollution incidents and promoting the removal of plastic wastes. For instance, the Dalian Volunteer Association and Blue Ribbon Ocean Conservation Society in Sanya (Hainan province) have removed waste from local beaches and seawaters in recent years. ${ }^{79}$ Beginning in 2007, Shanghai Rendu Ocean Center has mobilized thousands of volunteers in beach clean-ups and other voluntary waste removal initiatives. ${ }^{80}$

Rendu, based in Shanghai, proposed scientific methods to record and classify ocean wastes in order to monitor the state of China's marine wastes. ${ }^{81}$ The organization has published a series of reports on Monitoring Wastes in China's Several Symbolic Beaches in 2015, 2016, 2017, respectively. ${ }^{82}$ The reports provide scientific research information, which can be used by governments in pertinent policy-making. In 2017, in collaboration with East China Normal University, Rendu organized an Action on Monitoring and Cleaning Marine Plastics Pollution in Shanghai. ${ }^{83}$

\subsubsection{Private Companies}

Private companies in China, as well as small-sized businesses such as roadside stalls and local shops, play a crucial role in reducing plastics pollution, for example, by eliminating the single use of non-biodegradable plastic bags, supporting research, investing in alternative non-plastic products and

79 For more information on the efforts of China's NGO in addressing the MPP, see, Zhenjiao YANG, Xueming SUN and Linyun LUO, 'Research on the Policy Participation of the Environmental NGOs in China's Marine Environmental Governance' (2016) 35(3) Marine Environmental Science 444 .

8o Rendu Ocean, 'Love the Source of Life' Rendu, $2017<\mathrm{http} / /$ www.renduocean.org/ jingtanı.html>.

81 Ibid

82 The full version of the three reports can be accessed at Rendu Ocean $2017<\mathrm{http}: / / \mathrm{www}$ .renduocean.org/.

83 Kexin CAI, 'The First Initiative on Monitoring and Cleaning Marine Plastic Pollution was Carried Out', East China Normal University News Center, 1 April $2017<$ http://news.ecnu .edu.cn/63/10/c1833ago896/page.htm>. 
technologies that improve the efficiency of plastic waste recycling. Tianyuan Corporation and Jiuheng Tiaoma, for example, have increased investments in degradable plastic bags and recyclable tapes. ${ }^{84}$

Chinese giant e-commerce actors, including Alibaba, Jingdong and Suning have used various incentives (for example, price discounts and shopping coupons) to encourage consumers to choose green packaging in online orders, such as tape-free boxes and biodegradable packaging materials. ${ }^{85}$ As a pioneer, in 2017 Alibaba introduced a Green Logistics 2020 Plan, ${ }^{86}$ with the aim to use environmentally friendly packaging bags and recyclable boxes exclusively by $2020 .{ }^{87}$

In 2017, Meituan, one of China's largest online food ordering companies, started the 'Green Mountain Cooperative Initiative', which focuses on addressing the environmental problems associated with the food delivery industry. ${ }^{88}$ The primary objective of this initiative is to collaborate with different stakeholders to reduce packaging waste from source, improve recycling and promote environmental protection at the same time. ${ }^{89}$ Meituan has also established a partnership with Tsinghua University to conduct research on assessing the company's delivery impacts on environment as well as ways to improve its environmental sustainability. ${ }^{90}$ It can be argued that private companies in China increasingly realize the reputational benefits of a positive social image and there are definite signs of them working towards the reduction of plastic pollution.

84 Guangzhou Municipal Postal Administration, 'The New Innovation of Parcel Packages Reform: The 2017 Report on Green Package Development Situation and Trend in China's Delivery Industry' (Guangzhou Municipal Postal Administration Website, 18 October 2017), <http://gdgz.spb.gov.cn/zcfg_7527/201710/t20171018_1377459.html>.

85 Ibid.

86 See, Alibaba Group, 'Cainiao Leads Alibaba Group's Green Logistics 2020 Campaign' (Alibaba Group, 25 May 2018 <https://www.alibabagroup.com/en/news/article?news= p180525>.

87 Caijing Online, 'Alibaba Initiates the Green Delivery 2020 Plan and advocates for Green Packaging' China Daily, 24 May 2018 <http://caijing.chinadaily.com.cn/2018-05/24/ content_36261852.htm>.

88 For more information on the Green Mountain Initiative, see Meituan, 'Program', Meituan Dianping, 30 August $2018<$ https://about.meituan.com/detail-31.html >.

89 Ibid.

9o Ibid. 
This case study explores the main causes underlying the severe plastic pollution problem in Indonesia and the countermeasures that have been taken by various stakeholders. As mentioned in the introduction, Indonesia has been identified as the world's second largest source of MPP after China. ${ }^{91}$ It has been estimated that Indonesia generates 3.2 million tonnes of plastic waste that are unmanaged every year, of which 1.29 million ends up in the oceans and accounts for $16 \%$ of global M PP. ${ }^{92}$ Four of Indonesia's rivers (Brantas, Solo, Serayu and Progo) are on the list of the 20 most polluted rivers in the world. ${ }^{93}$ As the world's largest archipelagic state, Indonesia has more than 18,0oo islands, 7.9 million square kilometres of waters and more than 91,00o kilometres of coastline. ${ }^{94}$ This compounds the complexities of managing MPP in Indonesia.

\subsection{Plastic Pollution in Indonesia}

Many of the reasons behind the severity of the MPP problem in China that were explored in section 3 are also salient in the Indonesian context. First, the strong and sustained economic growth ${ }^{95}$ in Indonesia has facilitated industrialization and urbanization since the late $1960 s .{ }^{96}$ With a population of around 250 million people, Indonesia is the fourth most populous country in the world, and around $74 \%$ of Indonesia's population lives in coastal regions. ${ }^{97}$ The very poor waste disposal and management system in Indonesia has worsened over time, although plastic consumption of 17 kilograms per capita per year is much lower than in other countries. ${ }^{98}$

91 JAMBECK (n 18).

92 Ibid.

93 Laurent LEBRETON and others, 'River Plastic Emissions to the World's Oceans' (2017) 8(15611) Nature <https://www.nature.com/articles/ncomms15611>.

94 Robert CRIBB and Michele FORD, 'Indonesia as An Archipelago: Managing Islands, Managing the Seas' in Robert CRIBB and Michele FORD (eds) Indonesia Beyond the Water's Edge: Managing An Archipelagic State (Institute of Southeast Asian Studies, 2009), 1.

95 The World Bank data shows that the GDP in Indonesia was US\$ 932.26 billion in 2016, which grew from merely US $\$ 5.688$ billion in 1967 . In the past ten years, the rate of GDP growth in Indonesia has maintained between $4.63 \%$ to $6.35 \%$.

96 Stephen ELIAS and Clare NOONE, 'The Growth and Development of the Indonesia Economy' (2011) Reserve Bank of Australia (RBA) Bulletin <https://www.rba.gov.au/ publications/bulletin/2011/dec/pdf/bu-1211-4.pdf, 33>.

97 Muhammad ZIKRA, M. SUNTOYO and LUKIJANTO, 'Climate Change Impacts on Indonesia Coastal Areas' (2015) 14 Procedia—Earth and Planetary Science 57, 58.

98 BPF, 'Plastic Industry in Indonesia: BPF Report 2015' (2015) British Plastics Federation $<$ http://bpf.co.uk/exporters_toolbox/indonesia-report-2015.aspx>. 
The MPP problem in Indonesia bears its own distinct features, which warrants closer analysis, as well as the development of targeted solutions that are tailored to take these unique features into account. It should be emphasized that any portfolio of instruments to tackle MPP must take these regional differences into account since there is unlikely to be a 'one-size-fits-all' approach. First, given that Indonesia is located at the crossroads of some of the world's busiest maritime routes and neighbours a number of other coastal countries, ${ }^{99}$ the marine environment in Indonesia is unsurprisingly also affected by other countries in the region. This phenomenon is commonly referred to as 'foreign litter', which means that the ocean currents can cause plastic wastes to drift to Indonesia from other coasts even thousands of kilometres away. ${ }^{100}$ It is therefore an imperative that Indonesia seeks cooperation with its neighbouring countries to control and reduce plastic waste from entering into the ocean, as its own efforts will not be sufficient to address the 'foreign litter' issue. The importance of regional cooperation to address M PP in the Indonesian context cannot be over-emphasized.

Secondly, Indonesia's reliance on the tourism industry is reflected by the direct contribution of tourism to GDP, which reached US\$ 19.4 billion and amounted to $1.9 \%$ of total GDP in 2017. ${ }^{101}$ It is estimated that tourism will rise to US $\$ 37$ billion in 2028 and make up $2.1 \%$ of total GDP. ${ }^{102}$ Booming tourism can fuel consumption and is highly likely to lead to more plastic waste. How to effectively control and prevent MPP originating from tourism-related activities is crucial in Indonesia.

Thirdly, limited budgets, particularly of sub-national governments, have contributed to the prolonged plastic waste problem. ${ }^{103}$ Public expenditures on environmental protection in Indonesia are extremely low compared with

99 These include Australia, Brunei Darussalam, Cambodia, Malaysia, Papua New Guinea, the Philippines, Singapore, Timor-Leste and Vietnam.

100 Ministry of Tourism, Republic of Indonesia, 'The Government Is Taking Actions to Cleanse Bali's Sea from Drifting Litter' Wonderful Indonesia, 23 March $2018<$ https:// www.indonesia.travel/gb/en/news/the-government-is-taking-actions-to-bleanse -balis-sea-from-drifting-litters>.

101 WTTC, 'Travel \& Tourism Economic Impact 2018: Indonesia' (2018) World Travel \& Tourism Council <https://www.wttc.org/-/media/files/reports/economic-impact-research/ countries-2018/indonesia2018.pdf >.

102 Ibid.

103 Andi HAJRAMURNI, 'Indonesia Aims to Tackle Plastic Waste' (The Jakarta Post, 19 March $2018<$ http://www.thejakartapost.com/news/2018/03/18/indonesia-aims-to -tackle-plastic-waste.html>. 
other Asian countries. ${ }^{104}$ Sub-national Governments in Indonesia endure even deeper cuts in their budgets. ${ }^{105}$ When the central government fails to allocate sufficient budget to local governments, they have even more limited resources to deal with environment-related problems. ${ }^{106}$ The shortage of funding largely restricts local governments' capacity to handle MPP.

\subsection{National Legal and Institutional Frameworks}

The Indonesian central government has passed a number of laws that are relevant to MPP, such as the 2014 Law of the Sea, the 2009 Law on the Protection and Management of Environment, the 2008 Law on the Waste Management and the 1999 Law on Government Regulation concerning Control of Marine Pollution. None of these laws contain provisions that specifically address the issue of MPP.

The 2014 Law of the Sea is the overarching legal framework for regulating marine-related issues. ${ }^{107}$ Article 55 of this legislation states that central and regional governments shall establish a system for the prevention and mitigation of pollution and environmental damage in the oceans. Article 56 confers responsibilities on the central government for the protection and conservation of the marine environment through the prevention, reduction, and management of ocean pollution.

Similarly, the 2009 Law on Protection and Management of Environment, as an over-arching legal framework, does not specifically refer to MPP or plastic litter, but outlines general principles of environmental protection and management. ${ }^{108}$ Article 13 states that control of environmental pollution and damage shall include prevention, mitigation, and restoration. Marine

104 Jeffrey R. VINCENT and others, 'Public Environmental Expenditure in Indonesia' (2001) East Asia Environment and Social Development (EASES) Group Discussion Paper Series, 7 <http://documents.worldbank.org/curated/en/298481468756585486/Public -environmental-expenditure-in-Indonesia $>$.

105 Ibid.

106 Christia MEIDIANA and Thomas GAMSE, 'The New Waste Law: Challenging Opportunity for Future Landfill Operation in Indonesia' (2011) 29(1) Waste Management and Research $20<$ http://citeseerx.ist.psu.edu/viewdoc/download?doi=10.1.1.1031.7923\&re $\mathrm{p}=$ rep1\&type $=$ pdf $>, 21$.

107 It was adopted in October 17, 2014. For the English version, please see, Indolaw, 'Law No. 32 of 2014 on the Sea' <http://www.ilo.org/dyn/natlex/docs/ELECTRONIC/98587/117397/ F503452426/IDN98587\%20Eng:Idn.pdf>.

108 Law No. 32/2009 on Environmental Protection and Management was adopted on October 3, 2009. For the English version, please see 'Environmental Protection and Management' (The REDD desk, 9 November 2010 <https://theredddesk.org/sites/default/ files/ins97643.pdf>. 
pollution should be prevented through processes such as environmental impact assessment. The rules provide general guidance but are not enough to command specific actions to control MPP. In addition, the implementation of existing laws is weak, due to the shortage of human and financial resources and poor institutional capacity. ${ }^{109}$ Article 60 makes it unlawful to dump waste or materials into the environment without a permit. The prohibitions are reinforced by criminal sanctions for both individuals and corporations. ${ }^{110}$ Article 15 stipulates that authorities in sub-national governments are responsible for formulating environmental management plans. There are, however, no specific guidelines to further assist sub-national governments. ${ }^{111}$

Enacted in May 2008, the Waste Management Law is the first national law to address the waste issue in Indonesia. ${ }^{112}$ It empowers both national and local governments to deal with waste management, with local government being conferred an increasingly prominent role. ${ }^{113}$ The law aims to improve public health and environmental quality and utilize waste as an energy source. This law categorizes waste as follows: household waste, household-like waste and specific waste. ${ }^{114}$ According to Article 12, everybody is obliged to reduce and handle waste in an environmentally sound manner. Central and sub-national governments can impose penalties and criminal sanctions for infractions of the law. ${ }^{115}$ This law, however, does not refer to plastic waste specifically. Similar to the situation in China, regulations on product standards can potentially help reduce plastic pollution, for example if more strict standards on packaging or on the use of plastic materials are adopted. In Indonesia, the 2014 Act on Standardization and Accreditation, ${ }^{116}$ establishes a voluntary product standards system. Some standards, however, may be mandatory, related for

109 Ali BUDIARDJO and others, Law Reform in Indonesia: Diagnostic Assessment of Legal Development in Indonesia (Jakarta: Siber Konsultan, 1997).

110 These criminal sanctions can be found in Article 97 to 120 of Environmental Protection and Management Law No. 32/2009 (Indonesia).

111 Ibid.

112 The Waste Management Act No. 18/2008 (Indonesia) covers issues ranging from public service principles, waste management, including community-based waste management, private sector participation, and penalties for non-compliance. The full text is available at <https://www.ilo.org/dyn/natlex/natlex4.detail?p_lang=en\&p_isn= $84427 \&$ p_country=IDN\&p_count $=611>$.

113 Christia MEIDIANA (n 106) 21.

114 Art 2 of the Waste Management Law No. 18/2008 (Indonesia).

115 Ibid Art 29.

116 Standardization and Accreditation Act No. 20/2014 (Indonesia), Regulated by the System of National Standardization and Accreditation Regulation No. 34/ 2018 (Indonesia). 
example to safety, security, health or environmental protection. ${ }^{117}$ In practice, the Ministry of Industries determines which products are subjected to the national standardization system. ${ }^{118}$

The Indonesian government has also taken specific non-legislative measures aimed at reducing plastic waste. In 2016, Indonesia introduced a program in 23 cities that imposes a 200 rupiah (1 U.S. cent) price on the use of plastic bags, which generated $55 \%$ reduction in plastic waste over a three month trial period. ${ }^{119}$ After the trial period, retailers opposed the extension of this program, claiming that it was bad for their business and lacked legal grounds for enforcement. ${ }^{120}$ Environmentalists, on the other hand, were of the view that the price set on the use of plastic bags was too low to have any meaningful deterrent effect. ${ }^{121}$ The national government has been considering a tax on the use of plastic bags from 2019 to incentivize companies to produce environmentally friendly plastic bags. ${ }^{122}$

Indonesian President Joko Widodo pledged at the G2o Summit in Germany in 2017 to devote \$1 billion per year to reduce Indonesia's plastic and other marine waste by $70 \%$ by $2025 .{ }^{123}$ In the same year, the Indonesian government launched the National Ocean Policy, which includes the National Plan of Action on Marine Plastic Debris Management. ${ }^{124}$ This Plan proposes to address MPP in four ways: raising awareness, managing terrestrial and coastal plastic waste,

117 Article 24(1) Standardization and Accreditation Act No. 20/2014 (Indonesia).

118 The list of products is available (in Indonesian) at <http://pustan.kemenperin.go.id/ List_SNI_Wajib>.

119 Cory ROGERS, 'Indonesia, A Top Plastic Polluter, Mobilizes 20,00o Citizens to Clean Up the Mess' Mongabay, 4 September 2018 <https://news.mongabay.com/2018/og/ indonesia-a-top-plastic-polluter-mobilizes-200oo-citizens-to-clean-it-up/>.

120 Ibid.

121 For instance, Yew-Kwang NG, Albert WINSEMIUS, Chair professor of economics at Singapore's Nanyang Technological University expressed his concern: 'I strongly believe that the compulsory charges on plastic bags will be effective if imposed at appropriate levels, especially with some explanation to the public. I have not done a precise estimation, but 200 [rupiah] seems too low ... roughly 1000-2000 [rupiah] (\$0.08-\$0.15) would be better.' See, Euan BLACK, 'Indonesia's Plastic Bag Tax Not Enough, Say Experts', Southeast Asia Global, 6 September 2016) http://sea-globe.com/indonesia-plastic-bag-tax/>.

122 The Jakarta Post News Desk, 'Govt Drafts Plastic Bag Tax Regulation for 2019' The Jakarta Post, 24 August, 2018 <http://www.thejakartapost.com/news/2018/08/24/govt-drafts -plastic-bag-tax-regulation-for-2019.html $>$.

123 Johnny LANGENHEIM, 'Indonesia Pledges \$1 Billion A Year to Curb Ocean Waste' The Guardian, 2 March 2017 <https://www.theguardian.com/environment/the-coral -triangle $/ 2017 / \mathrm{mar} /$ o2/indonesia-pledges-usi-billion-a-year-to-curb-ocean-waste>.

124 For the full text of Indonesia's Plan of Action on Marine Plastic Debris, please see, Deputy for Human Resources, Science, Technology and Maritime Culture, 'Indonesia's Plan of Action on Marine Plastic Debris 2017-2025 Executive Summary' 
managing marine debris, and providing funding and institutional support. ${ }^{125}$ This shows that the national government recognizes the imperative to control MPP. However, we contend that merely having action plans 'on the books' is not sufficient. These plans announced by the government must be translated into action.

Despite the laws, administrative rules and action plans put in place, the MPP problem in Indonesia has not been effectively addressed over the years. ${ }^{126}$ This failure can be attributed to a number of reasons: there is no national law that specifically deals with MPP and creates mechanisms to address the problem, and law enforcement in Indonesia is generally weak. Reasons for weak enforcement are multifold. For example, courts in Indonesia have limited authority to directly implement their own decisions. ${ }^{127}$ In addition, it is arguable that overlapping authority at the provincial, regional and district levels generate uncertainties on the exact scope of regulation. ${ }^{128}$ In view of the gaps in current laws and enforcement issues in Indonesia, other stakeholders are taking action to control MPP. These include sub-national governments, businesses, NGOS, religious groups and individuals.

\subsection{Sub-national Frameworks}

Indonesia is divided into five levels of government: central, provinces, districts and municipalities, sub-districts and villages. ${ }^{129}$ This section refers to the governing bodies of these various levels of government below the central level as 'sub-national governments'. With the 1999 Law on Decentralization and Regional Autonomy, the central government in Indonesia transferred

(indonesianwaste.org, 10 March 2018) <http://www.indonesianwaste.org/en/indonesias -national-plan-of-action-on-marine-plastic-debris-2017-2015-executive-summary-2/>.

125 Ibid 4.

126 According to the World Bank, Indonesia dumped around 0.48 to 1.29 million metric tons of plastic waste into the ocean in 2010, 'Indonesia Marine Debris Hotspot' April 2018, $<$ http://documents.worldbank.org/curated/en/983771527663689822/pdf/126686 -29-5-2018-14-18-6-SynthesisReportFullReportAPRILFINAL.pdf> 2. In 2015, according to JAMBECK, Indonesia discharged around 3.22 million metric tons of plastic waste to the ocean, see JAMBECK et al (n 18).

127 David NICHOLSON, Environmental Dispute Resolution in Indonesia (Brill, 2009) 110; Tim LINDSEY and Simon BUTT, Indonesian Law (Oxford University Press, 2018) 84, 98-100.

128 IDLO, 'Strengthening Environmental Law Compliance and Enforcement in Indonesia' (2006) International Development Law Organisation <http://www.idlo.org/publications/ 30.pdf, 4-5>.

129 Anwar NASUTION, 'Government Decentralization Program in Indonesia' (2016) Tokyo: Asian Development Bank Institute (ADBI) Working Paper Series 601/2016 <https://www .adb.org/sites/default/files/publication/201116/adbi-wp6o1.pdf>. 
further responsibilities to sub-national governments, in areas such as health, education, transport, agriculture and environment. ${ }^{130}$ Decentralization confers more autonomy to sub-national governments to create policies and measures to deal with several matters, including MPP. For example, the 2009 Act on Environmental Protection and Management authorizes provincial governments to adopt certain environmental taxes, which are a levy imposed by the government on the use of natural resources. ${ }^{131}$ They include taxes on groundwater extraction, on fuel use and on Swift's nests, ${ }^{132}$ which can be also imposed and further regulated by local governments. Taxes enacted by local governments are regulated under the 2009 Act 28 on Local Taxes and Levies. ${ }^{133}$ According to the 2017 Regulation on Economic Environmental Instruments, taxes can be collected by both the central government and local governments. ${ }^{134}$ This Regulation stipulates that subsidies can apply to those who produce environmentally-friendly goods or services, use technology to restore ecological functions or adopt businesses practices that prevent pollution or environmental damage. ${ }^{135} \mathrm{~A}$ nation-wide plastic tax is currently in the making by the Indonesian Government, in addition to the existing Regulation to incentivize companies to produce environmentally friendly plastic bags. ${ }^{136}$ These laws and regulations can play a significant role in efforts to reduce plastic pollution.

130 The first law was enacted in 1999 and was effective in 2001. It was revised three years later in 2004. The second revision was in 2014 when the Law No. 23/2014 on Local Government was enacted.

131 See, Art 43 of Environmental Protection and Management Law Act No. 32/2009 (Indonesia).

132 Art 43, 3 (b), Indonesia's 2009 Environmental Protection and Management Act 32/2009 (Indonesia).

133 Act 28 on Local Taxes and Levies Act No. 28/2009 (Indonesia).

134 Art 38 (1), Regulation on Economic Environmental Instruments No. 46/2017 (Indonesia). This Regulation stipulates that taxes may be imposed on the extraction or use of groundwater, surface water, swift's nests, minerals and metals, fuels, and other activities (Art 39, 1). Indonesia's Ministry of Finance formulated a Guideline for local governments on different types of taxes that they can impose, considering the categories established by Act No. 32/2009. This Guideline covers a variety of taxes, such as surface water tax, non-metal and non-earth/rock mineral tax. The full text of the Guideline is available (in Indonesian) at $<$ http://www.djpk.kemenkeu.go.id/?p=10769>.

$135 \operatorname{Art} 41(1)$.

136 See press news from the Jakarta Post News Desk, 'Government Drafts Plastic Bag Tax Regulation for 2019' The Jakarta Post, 24 August, 2018 <http://www.thejakartapost.com/ news/2018/08/24/govt-drafts-plastic-bag-tax-regulation-for-2019.html>, also (in Indonesian) <https:/www.cnnindonesia.com/ekonomi/20170226021832-78-196204/dinilaimanjur-pemerintah-koordinasi-pajak-kantong-plastik>. 


\subsubsection{Sub-national Governments}

An increasing number of sub-national governments are drafting regulations to address plastic pollution. In June 2016, the city of Banjarmasin became the first in Indonesia to prohibit the use of plastic bags in the retail sector. ${ }^{137}$ It has been estimated that this measure has prevented the use of $5^{2}$ million plastic bags monthly and the government is considering the expansion of the scope of this ban to include traditional markets. ${ }^{138}$

In Bali, an internationally renowned tourist destination, local authorities in 2017 declared a state of 'garbage emergency' across a 3.6 kilometre stretch of coast on the island and deployed a task force, including cleaners and trucks, to remove several tonnes of waste. ${ }^{139}$ The Balinese local government also spent US\$ 1 million on a recycling facility to better manage plastic waste. ${ }^{140}$ Under the mounting pressure created by an NGo called Bye Bye Plastic Bags (вв Рв), the Bali governor signed a memorandum of understanding by which it committed to becoming a 'plastic-bag free Bali' by the end of 2018. ${ }^{141}$

The Minister of Environment introduced a "Waste Bank" initiative in 2008 to reduce, reuse and recycle waste, in which regional governments have a proactive role in implementing the policy and mobilizing civil society. ${ }^{142}$ The first Waste Bank was established in Bantul, Yogyakarta in 2008, and the number has increased rapidly since then. ${ }^{143}$ At waste banks, the waste created by households is divided into organic and non-organic, the latter including plastic,

137 Hasan ZAINUDDIN, 'Banjarmasin Keeps Banning Plastic Bags' (Antarnanews, 19 September 2018) <https://kalsel.antaranews.com/berita/71857/banjarmasin-keeps -banning-plastic-bags $>$.

138 Ibid.

139 Michael TAYLOR, 'Trash Heroes and Scavenger Apps Battle Bali 'Garbage Emergency” Reuters, 23 July 2018 <https://www.reuters.com/article/us-islands-indonesia-bali-waste/ trash-heroes-and-scavenger-apps-battle-bali-garbage-emergency-idUSKBNıKDo4K>.

140 Ibid.

141 McKinley TRETLER, 'Will Bali Be Plastic Bag Free by 2018?' (Assembly, 15 August 2018) $<$ https://assembly.malala.org/stories/bali-plastic-bag-free>.

142 For more information on the establishment and operation of Waste Bank in Indonesia, see Temesi Recycling, 'Waste Banks' http://temesirecycling.com/waste-banks/. For information on the so-called 3-Rs (reduce, reuse and recycle), see, Farizal FARIZAL and others, 'Indonesia's Municipal Solid Waste $3 \mathrm{R}$ and Waste to Energy Programs' (2017) 21(3) Industrial Engineering 153; Ir. Enri DAMANHURI, 'State of the ${ }_{3}$ Rs in Asia and the Pacific' (2017) United Nations Centre for Regional Development, <http://www.uncrd.or.jp/ content/documents/5689[Nov\%202017]\%20Indonesia.pdf>.

143 Dyah Retno WIJAYANTI and Sri SURYANI, 'Waste Bank as Community-Based Environmental Governance: A Lesson Learned from Surabaya' (2015) 184 ProcediaSocial and Behavioral Science (2015) 171 <https://www.sciencedirect.com/science/article/ pii/S187704281503326>. 
paper, bottles and metal. ${ }^{144}$ Individuals are encouraged to separate and bring non-organic waste to the bank, which is accounted as 'bank deposits,' and the waste is given a monetary value. ${ }^{145}$ Other Indonesian cities, such as Depok, have sought collaboration with the city of Osaki in Japan to learn and improve waste management practices. ${ }^{146}$

In 2018, the local government of Surabaya, Indonesia's second-largest city, introduced a new policy to encourage residents to ride city buses for free by dropping off plastic bottles at terminals or directly paying the fare with plastic bottles. ${ }^{147}$ Each bus collected around 7.5 tonnes of plastic bottles, which were then given to recycling companies. ${ }^{148}$ This is one of the initiatives to meet Surabaya's ambitious target to be free of plastic by $2020 .{ }^{149}$

\subsubsection{Religious Groups}

Indonesia is home to the largest Muslim population in the world ${ }^{150}$ and it can be argued that religion has an important role in tackling MPP in Indonesia. The Fatwa (Islamic Legal Pronouncement) 2014 Waste Management to Prevent Environment Degradation declares that it is the responsibility of every Muslim to keep the environment clean. ${ }^{151}$ It prohibits the disposal of trash or items that are still usable..$^{152}$

The role that religious leaders are playing in combating plastic pollution cannot be underestimated. The two largest Muslim groups in Indonesia,

144 Randy SALIM, 'Waste Not, Want Not: Waste Bank in Indonesia' World Bank Blogs, 19 December $2013<$ http://blogs.worldbank.org/eastasiapacific/waste-not-want-not-waste -banks-indonesia >.

145 Ibid.

146 Paula MIQUELIS and Ashwin SUBRAMANIAM, 'Depok: The Front Line in Indonesia's Fight against Waste' (21 August 2017) Jakarta Post, <https://www.thejakartapost.com/ life/2017/08/21/depok-the-front-line-in-indonesias-fight-against-waste.html>.

147 Prasto WARDOYO, 'Plastic to Ride: Indonesians Swap Bottles for Bus Tickets' Reuters, 23 October 2018 <https://www.reuters.com/article/us-indonesia-environment-plastics -bus/plastic-to-ride-indonesians-swap-bottles-for-bus-tickets-idUSKCNıMXıOD>.

148 Ibid.

149 Ibid.

150 According to official data, around $13 \%$ of the total number of Muslims in the world live in Indonesia, which implies that Indonesia contains a clear Muslim majority population. See, 'Islam in Indonesia' (Indonesia-Investments) <https://www.indonesia-investments. com/culture/religion/islam/item248>.

151 For the full text in Indonesian language, please see the website of the MUI Institute for Environmental Breeding and Natural Resources (mui-Iplhsda.org, 9 December 2014) $<$ https://mui-lplhsda.org/fatwa-majelis-ulama-indonesia-nomor-47-tahun-2014-tentang -pengelolaan-sampah-untuk-mencegah-kerusakan-lingkungan/>.

$15^{2}$ Ibid. 
Nahdlatul Ulama and Muhammadiyah, which have more than 100 million followers, have encouraged the use of reusable bags (in lieu of non-recyclable bags) in various religious activities. ${ }^{153}$ Religious leaders have also visited mosques across the country to preach about the need to reducing plastic waste, and switch to reusable bags made from materials such as rattan and bamboo. ${ }^{154}$ Some Islamic boarding schools have introduced courses that raise students' awareness and provide recycling programs. ${ }^{155}$ Nahdlatul Ulama and Muhammadiyah joined the Indonesian Ministry of Forestry and Environment in launching the Plastic Waste Reduction Movement in June 2018. Religious leaders have also been invited by the Indonesian central government during the Ramadan to speak against plastic waste and encourage their followers to adopt environmentally conscious practices. ${ }^{156}$

\subsubsection{NGOS}

An increasing number of NGOs in Indonesia have enthusiastically engaged in combating MPP by educating school children, cleaning up beaches and advocating for better waste management. This is particularly notable in Bali, due to its tourism-dependent economy and need for environmental conservation. For example, in 2018, в в в оrganized the largest beach clean-up initiative in Bali, One Island One Voice, which rallied a large amount of people and removed several tonnes of waste. ${ }^{157}$ In 2019 there were several clean-ups in Bali, involving thousands of participants. ${ }^{158}$

вв Рв was established in 2013 by two girls in Bali, who were just 10 and 12 years old ${ }^{159}$ with the mission to ban the use, sale and production of plastic bags across the island of Bali. в в в has raised thousands of signatures for an online petition to urge the local government to implement a plastic bag ban

153 Moses OMPUSUNGGU, 'Indonesia's Latest Weapon to Cut Plastic Bag Use: Devout Muslims' The Jakarta Post, 6 June 2018 <http://www.thejakartapost.com/news/2018/06/05/ indonesias-latest-weapon-to-cut-plastic-bag-use-devout-muslims.html>.

154 Kate LAMB, 'Preaching Against Plastic: Indonesia's Religious Leaders Join Fight to Cut Waste' The Guardian, 7 June 2018 <https://www.theguardian.com/world/2018/ jun/o7/indonesia-plastic-rubbish-religious-leaders-join-fight-to-cut-waste>.

155 Ibid.

156 Ibid.

157 For further information, see NOW! Bali Magazine, $2018<$ http://nowbali.co.id/event/ balis-biggest-beach-clean-up/.

$15^{8}$ For example, the One Island One Voice clean-up event of 16 February 2019 gathered 13,000 people in 150 locations and collected over 30 tonnes of plastic, see $<$ https://www.one islandonevoice.org>.

159 For more information on вврв, see the official website $<$ http://www.byebyeplasticbags .org/about/>. 
in Bali. ${ }^{160}$ In 2014, a Memorandum of Understanding was signed by Вв Рв and Bali's Governor to take measures to reduce and eliminate the use of plastic bags. ${ }^{161}$ The founders of вврв have given presentations at schools and have established a pilot scheme in Bali villages to promote zero use of plastic bags. ${ }^{162}$ Although NGOs in Indonesia did not start to address MPP until very recently, their efforts are increasingly prominent and powerful, particularly in tourist destinations such as Bali. However, many campaigns and activities led by NGOs in Indonesia are limited in scope, ad hoc and under-funded, with little capacity to address the massive plastic pollution problem.

\subsubsection{Private Businesses}

The private sector, including small and large-sized companies, has addressed MPP in a variety of ways. For example, an Indonesian start-up company Evoware has promoted a seaweed-based packaging initiative which is $100 \%$ biodegradable, can dissolve in warm water and has a two-year shelf life without preservatives. ${ }^{163}$ This also creates business opportunities for seaweed farmers' and reduces its oversupply of seaweed in the country. ${ }^{164}$ In 2017 , Evoware won the Circular Design Challenge in an international competition organized by the New Plastics Economy, an initiative led by the Ellen MacArthur Foundation. 165

Avani is a Bali-based private company set up in 2014 to promote technologies and solutions to combat plastic pollution. ${ }^{166}$ Avani provides biodegradable and compostable bags made out of the root vegetable cassava. ${ }^{167}$ Similarly, a Bali-based company, Eco Bali provides waste management, composting and recycling assistance to households and businesses, charging a small fee. ${ }^{168}$ It also provides environmental education and building waste collection infrastructure in schools. ${ }^{169}$

\footnotetext{
160 Ibid.

161 Ibid.

162 Namhar HERNANTO, 'Eradicating Plastic in Bali’ NOW! Bali Magazine, 28 February 2017 $<$ http://nowbali.co.id/eradicating-plastic-bali/>.

163 See the Evoware Website, Evoware, <'About Evoware: Our Story' http://www.evoware.id// about_us/our_story >.

164 Ibid.

165 Ibid.

166 For more information, see the Avani Website, Avani, 'REPLACE Plastic with solutions made from renewables' <https://www.avanieco.com/>.

167 Ibid.

168 See, Eco Bali, 'Responsible Waste Management and Sustainable Lifestyle in the Island of Bali' <http://eco-bali.com/>.

169 Ibid.
} 
The contribution of large-sized multinational companies in addressing Indonesia's MPP also merits attention. Nestlé Indonesia has introduced the optimization of plastic wrapping of finished goods and empowers local factories to manage their waste properly by eco-friendly means. ${ }^{170}$ Nestlé has proposed the idea of 'zero waste' along the value chain, which has motivated hundreds of thousands of Indonesian farmers, who are Nestlés suppliers, to reduce waste. ${ }^{171}$

Nestlé also built an alliance with other five companies in creating PRAISE (Packaging and Recycling Alliance for Indonesia Sustainable Environment) to support an eco-friendly, integrated waste management system. ${ }^{172}$ Another illustrative example is Borealis AG, which is a global plastic producer that has donated most of the funding for the project STOP Ocean Plastics in 2017. ${ }^{173}$ Banyuwangi in Indonesia was selected in 2018 as the first beneficiary city under this project, with its fishing port Muncar being the pilot site. ${ }^{174}$ The aim is to reduce and eliminate leakage of plastics into the environment. ${ }^{175}$

\section{5}

\section{An 'All Hands on Deck' Approach: Lessons from China and Indonesia}

Based on the two case studies, this article eschews a merely state-centric approach because it is clear from our findings that MPP can be more effectively handled through an 'all hands-on deck' approach. This involves a multi-level and multi-actor strategy to tackle plastic pollution. In terms of regulatory measures, this approach requires the adoption or strengthening of certain domestic laws, notably waste management and recycling laws, but also non-regulatory measures, such as public campaigns and education, as well as policies and initiatives led by local governments, NGOS and the private sector.

\footnotetext{
170 See Nestlé, 'How Are You Tackling Plastic Waste in Indonesia?' <https://www.nestle .co.id/eng/ask-nestle/nestle-in-indonesia/environment/greenpeace-plastic-waste -research-finding >.

171 Ibid.

172 Ibid. The other five companies are: PT Coca-Cola Indonesia, PT Indofood Sukses Makmur, твк, PT Tetra Pak Indonesia and PT Tirta Investama dan Yayasan Unilever Indonesia.

173 Borealis Group, 'Next Phase of Project STOP Ocean Plastics Announced in Indonesia' (Borealis Media Release, 26 April 2018) <https://www.borealisgroup.com/news/borealiscommitted-to-helping-to-solve-the-problem-of-ocean-plastic >. Project STOP is a new initiative to design, implement and scale circular economy solutions to marine plastic pollution, focused on countries with a high leakage of plastics into the oceans. Indonesia is on the list of countries that this Project deals with.

174 Ibid.

175 Ibid.
} 
This article argues that an 'all hands on deck' approach is suitable because plastic pollution is generated by multiple stakeholders (e.g. individuals, institutions, corporations) operating at various levels (such as city, provincial and national levels). The problem can get better or worse depending on the adequacy of (regulatory and non-regulatory) measures in place. These include not only laws and national policies, but also non-governmental and industry-led strategies and initiatives. Thus, to handle MPP, multiple stakeholders need to act at different levels and use a combination of measures. To tackle a problem as big and pervasive as MPP, we need all hands on deck. In practice, governance efforts taken by public and private actors often involve partnerships, for example between governments and the industry or between cities, as noted in the case studies. Although MPP requires a multi-level and multi-actor strategy, we argue that the most specific efforts should be at the city-level, particularly coastal cities where the problem mainly originates.

\subsection{Strengthening Local Waste Management and Recycling Laws}

Most plastic waste is generated in cities and other human settlements and, due to poor waste management and dismal recycling rates, plastics end up in the rivers and ultimately in the ocean. It is thus pivotal to create or improve waste management and recycling laws to reduce plastic pollution. Improving waste disposal and management in developing countries will also go a long way to improving public health and environmental quality.

The case studies reveal a number of issues concerning China and Indonesia's regulatory and institutional frameworks. There are no national laws that specifically address MPP in either country although certain domestic laws indirectly deal with it, for example on the law of the sea, environmental protection and waste dumping. Certain sub-national regulations are also directly relevant, for example on packaging or on plastic bag use (e.g. Shanghai's 2013 Regulations on Reducing Packaging and Jilin's 2015 Regulation on Producing, Selling and Providing One-Time Non-Degradable Plastic Bags and Tableware). The lack of dedicated laws means that there are no specific regulatory mechanisms tackling MPP. It is also noted that MPP is not yet a priority item in the environmental policy agenda of some countries, including China.

Even if domestic laws are adopted, their implementation and enforcement may prove challenging, as observed with current environmental laws in both case studies. This reinforces our argument that a mix of (regulatory and nonregulatory) measures is required for handling MPP, as discussed below. The institutional framework in both countries is fragmented with regard to plastic 
pollution. There are various agencies that can deal with it, but none of them have a defined leading role.

Partly due to the insufficient domestic laws systematically regulating waste disposal and management, both countries studied suffer from inadequate facilities, poor waste management practices and technology, including for waste collection and treatment. The lack of an adequate waste management system is at the heart of the MPP problem. The arrangements that are in place in China and Indonesia, as shown in the case studies, are inadequate to address massive plastic waste generation.

Drawing from the case studies, there are at least two crucial normative actions required. Firstly, countries should either create specific MPP laws or strengthen existing waste management laws. Secondly, they should devise adequate compliance and enforcement mechanisms for existing laws or new laws. If specific MPP laws are adopted, they will be most effective, in terms of their content, if they provide clear guidance on certain key aspects including clarity on who the law applies to. Ideally, they should include individuals, households, public institutions and private companies. Further, they should establish 'who-does-what.' As observed, the current institutional frameworks in China and Indonesia are highly fragmented in relation to plastic pollution and no government agency has a clear and defined leading role. Efforts to tackle MPP thus tend to be uncoordinated and, in practice, mostly focused on popular tourist destinations. MPP laws should therefore create clear obligations and well-defined responsibilities for those responsible for their implementation. For example, legal obligations could typically include the duty to reduce plastic use, recycle, and prohibit waste dumping. Producer responsibility clauses ought to be introduced to address issues concerning the use of materials, packaging, recycling practices and waste disposal. Further, MPP laws should create compliance mechanisms, with penalties for non-compliance and possibly a reward system for those that abide by the law, for example through tax incentives, subsidies or other mechanisms. For instance, corporations that use alternative non-plastic materials, introduce new technology or recycling practices that result in reduced plastic use could be rewarded for best businesses practices. Finally, MPP laws should clearly confer responsibility and power on the relevant enforcement agencies. As observed in the two case studies, the great challenge is to ensure adequate implementation and high levels of compliance. In response, MPP laws must establish mechanisms that are strong enough to encourage law-abiding behaviour and penalize non-compliance.

Although important, specific MPP laws alone will not be enough to tackle marine plastic pollution. This is because MPP is a complex issue, originating 
from various sources and engaging different levels of governance. Therefore, we propose a mix of regulatory and non-regulatory measures, which are discussed below. These measures include education and raising awareness about plastic consumption habits and best business practices, which may lead to major changes in production and consumption patterns. Even if a country has adequate MPP laws and high levels of compliance, the problem may still persist, as MPP involves transboundary pollution and affects all countries. As discussed below, we suggest emphasis on inter-state and regional partnerships in Asia and other parts of the world.

There can be different indicators for measuring how effective a mix of (regulatory and non-regulatory) measures has been in a given country. They may include, for example, the number of laws and policies that address MPP, the number of institutions (and staff) with direct and defined responsibility to tackle MPP, the level of funding allocated to implementing MPP laws and policies, the number and scope of education and awareness campaigns, the number of public-private partnerships created as a result of MPP laws and policies, etc. These could all be indicators to show changes in the real world, as a result of a mix of measures to tackle MPP. The ultimate outcomes will be the measurable reduction of plastic waste and the actual change of production and consumption behaviour. This is observed, for example, when large supermarket chains offer cardboard boxes for groceries, instead of single-use plastic bags, and have strict 'bring your own bag' policies, which result is the reduction of plastic use and waste. ${ }^{176}$

In sum, stronger national and institutional frameworks for tackling plastic pollution will likely contribute to improving the current waste management practices in both countries studied. There have also been significant efforts taken at the sub-national level driven by local governments and non-state actors, as noted in the cases studies. Some of these measures have been more effective than those taken by central governments, and include examples of non-regulatory measures.

\subsection{Education and Awareness on Plastic Consumption Habits}

Regulatory measures, including domestic laws regulating waste management and recycling, banning single-use plastic bags or prohibiting waste dumping,

${ }_{176}$ For example, Aldi supermarkets in Australia no longer offer customers single-use plastic bags, see <https://www.aldi.com.au/en/about-aldi/responsibility-at-aldi/>. However, Aldi's practice of plastic-wrapping fruit and vegetables has been criticized, see $<$ https://www.news.com.au/technology/environment/aldi-big-offender-when-it-comes -to-plasticwrapped-fruit-and-veg/news-story/ec40035adab6ee4c151554bbbf2fcd2d>. 
should be accompanied by other non-regulatory measures, for example those that raise awareness and help change consumer behaviour. This is also required to avoid public backlash in communities where the use of plastic bags is ubiquitous and where plastic use bans are likely to be viewed as placing an unfair burden on the less well-off.

As shown in both case studies, the work of NGOs has helped raise awareness and promote education among individuals and communities (in schools, local councils, etc.) through public campaigns and beach clean-ups. In Indonesia, for instance, a number of NGOs engaged in reducing plastic pollution, such as ВВРВ, have provided information to consumers and contributed to education in schools and communities about the harmful impacts of plastic pollution. Other stakeholders, such as prominent Muslim groups in Indonesia, have raised awareness about plastic pollution among millions of religious followers. Some initiatives in China, such as that led by Rendu, have also helped generate knowledge and are monitoring ocean wastes.

The efforts led by individuals, NGOS and civil society groups, as mentioned in the case studies, are also complementary to the measures taken by local governments that often operate with small budgets and limited capacity. However, many of those efforts, as noted in Indonesia, have a limited scope, as they focus on specific areas such as touristic destinations, and operate with low budgets for a limited period of time. Although important, these efforts alone are insufficient to handle the massive MPP problem in the two countries.

\subsection{Reducing Plastics Pollution as Part of Corporations' Business Practices and Policies}

The private sector plays an essential role in reducing plastic pollution. Corporations can assist in various ways, for example in changing business-asusual practices (e.g. packaging practices, choice of materials, etc.), investing in new technology, changing consumers' habits and also building partnerships with governments and other stakeholders. ${ }^{177}$ The funding from large-sized companies can also alleviate the financial burden faced by many sub-national governments in the battle against MPP, as noted in Indonesia.

It is observed in the two case studies that corporations are increasingly part of the efforts against plastic pollution. Examples of important industry action include: change of industry practices (e.g. policies against excessive packaging, declarations on 'green takeaway,' etc.): investment in research and development, leading to new materials and technology (e.g. biodegradable plastic

177 See Peter DAUVERGNE, 'The Power of Environmental Norms: Marine Plastic Pollution and the Politics of Microbeads' (2018) 27(4) Environmental Politics 579. 
bags, alternatives to plastics, recycling etc.), and industry-led change of consumer behaviour (e.g. Alibaba Jingdong and Suning price discounts and shopping coupons). Both case studies indicate that private sector involvement has been positive in reducing plastic pollution. Further industry participation, notably of key sectors such as the tourism industry in Indonesia, is pivotal for any efforts to reducing MPP. Corporations should also be encouraged to include the reduction of plastics use in their corporate social responsibility (CSR) and other policies.

\subsection{Building Multi-stakeholder and Cross-border Partnerships}

Many of the initiatives carried out at the sub-national level examined in both case studies involve public-private partnerships. In practice, a number of partnerships are being formed between different stakeholders, for example between the following: private sector and the government (e.g. Shengda Biological and Zhengjiang Haizheng being incentivized by the local government through fiscal policies); civil society and the government (e.g. Muslim groups in Indonesia joining efforts with the Ministry of Forestry and Environment): NGOs and the government (e.g. agreement between вв Рв and Bali's governor to eliminate plastic bags): NG Os and academia (e.g. collaboration between Rendu, a Shanghai-based organization, with East China Normal University); and between companies (Alibaba partnering with L'Oréal in China to improve packaging practices, or the Green Takeaway Alliance amongst takeaway companies).

There are also examples of collaboration between cities located in different countries (as noted, for example, between Depok in Indonesia and Osaki in Japan regarding waste management practices). Examples such as this are likely to increase between cities and among countries as MPP is a cross-border and widespread problem affecting all countries. No significant regional platform or initiative involving Asia-Pacific countries in combating MPP has yet emerged. However, ASEAN has recently urged countries to use regional cooperation to address MPP. ${ }^{178}$ Inter-state cooperation is indeed essential to tackle common problems that require joint actions, for example that of 'foreign litter' in Indonesia's territorial seas. Regional cooperation would also be instrumental to set standards for environmental management in the Asia-Pacific region. ${ }^{179} \mathrm{It}$ is submitted that ASEAN should consider drafting a declaration or action plan

178 ASEAN, Reducing Marine Debris (n 6).

179 See Ben BOER, 'Environmental Law in Southeast Asia' in Philip HIRSCH (ed) Routledge Handbook of the Environment in Southeast Asia (Routledge, 2017) 115. 
tackling MPP in the region, in order to encourage all ASEAN states both to cooperate and to enact legislation addressing marine plastic pollution.

\section{$6 \quad$ Conclusion}

MPP is a widespread problem affecting many countries, particularly in the Asian region, and generated mostly from land-based sources. Five Asian countries, namely China, Indonesia, the Philippines, Vietnam and Sri Lanka, are the most polluting countries globally. This article focused on the two top plastics polluters: China and Indonesia. Both countries face similar challenges in dealing with M PP. In particular, they have weak legal and institutional frameworks in place to deal with plastic pollution. To date, they have no specific laws or mechanisms on MPP and an ill-defined institutional structure regarding plastic pollution. It is also observed that both countries have issues with the implementation and enforcement of current domestic environmental laws, although, in China, this is beginning to be addressed. ${ }^{180}$ In addition, there is limited funding for local governments to deal with the massive and ever-growing plastic pollution.

The two case studies have shown that there have been more creative and effective measures taken at the sub-national level by local governments and non-state actors, many of which involve partnerships among different stakeholders. Efforts to reduce MPP have been observed, particularly in densely populated coastal cities and popular tourist destinations. The trend of decentralization, observed in Indonesia, is also likely to give a more prominent role to local governments. Sub-national governments might encounter an array of obstacles in tackling environmental issues, such as the lack of political will or capacity, limited financial means, pressure from business interests, ${ }^{181}$ but their role in controlling MPP is essential.

This article argued that governance efforts to address MPP require an 'all hands on deck' approach, involving a multi-level and multi-actor strategy to tackle plastic pollution, and targeted regulatory (and non-regulatory) measures. In any case, as argued, governance efforts to address plastic pollution should be mostly at the city level. 182

180 See Wang JINPENG ( $\mathrm{n}$ 57), Yun MA (n 72), Richard ZHANG Qing and Benoit MAYER (n 72$)$.

181 Adriaan BEDNER, 'Consequences of Decentralization: Environmental Impact Assessment and Water Pollution Control in Indonesia' (2010) 32(1) Law \& Policy 38, 40.

182 See Section 3. 
There are several key lessons and policy recommendations that can be drawn from the two case studies. This article suggests that there is a need to: create specific MPP laws or strengthen existing national laws, notably waste management and recycling laws, as well as local government ordinances: raise public awareness and educate consumers on plastic consumption habits: reduce plastic pollution as part of corporations' business practices: and build multi-stakeholder and cross-border partnerships for combating plastic pollution. These governance efforts are likely to be more effective if taken in a coordinated and holistic way. 